
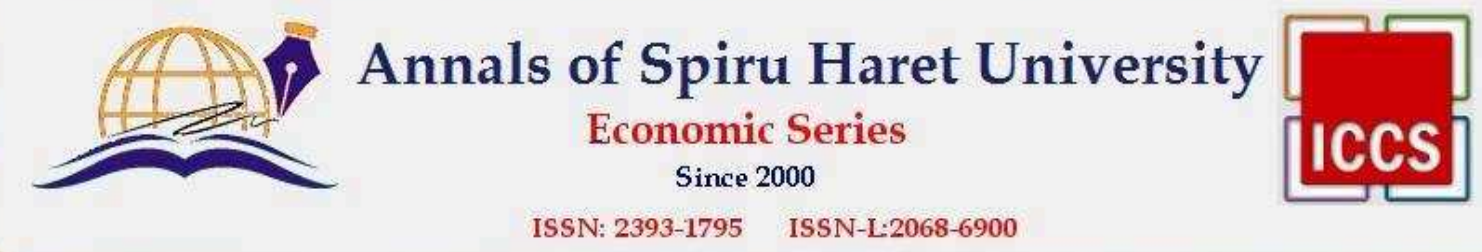

Issue $1 / 2016$

\title{
PENSION SYSTEM METHODOLOGY FOR SENIOR CITIZENS
}

\author{
Titel NEGRU \\ "Spiru Haret" University, Ion Ghica, no. 13, Bucharest, 030045, Romania \\ Tel: +40214551000, Fax: +40213143900 \\ Email: titel_negru@yahoo.fr
}

\begin{abstract}
The need to reform pension systems is one of the key social challenges for policy-makers in Europe. The demographic evolutions of the last 26 years, the changes in the Romanian economy and society influenced one particular category - the retired people. As population inactive, retired people represents an important year category, their numbers being rather big in comparison with the population employed, the practical pensions contributors are at the bottom with their funds.

Key words: social protection; public system; pension; retirement age standard; the minimum contribution; contribution complete period; social security system.
\end{abstract}

JEL Classification: D63

\section{Introduction}

Like other countries, Romania has a system of social protection and the most important component is the pension system, which represents the largest category of public spending.

The right to social security is guaranteed by the state and is exercised according to law by the public system of pensions and other social insurance rights, generically known as the public system. 


\section{Annals of Spiru Haret University \\ Economic Series \\ Since 2000 \\ ISSN: $2393-1795 \quad$ ISSN-L:2068-6900}

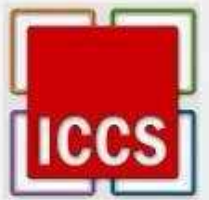

Issue $1 / 2016$

In the public system are insured according to the legal provisions individuals generally called insurants.

According to the unitary public pension system [Law no. 263, 2010], the insured shall be considered the "individual for whom the employer is required to withhold and pay the individual social insurance contribution as well as the individual who pays, on his own account, social insurance contribution."

Retirement pension is the main category of pension allowed in the state system, and in order to receive it, citizens must meet two conditions. These are reaching the standard retirement age and achieving the minimum contribution period, both calculated based on date of birth.

\section{Basics principles}

The public pension system is organized and operates having as basic principles [Law no. 263, 2010]:

a) uniqueness principle, according to which the state organizes and guarantees the public pension system based on the same rules of law for all participants in the system;

b) compulsoriness principle, according to which natural and legal persons have, according to the law, the obligation to participate in the public pension system, social security rights exercising correlatively with the fulfilment of obligations;

c) contribution principle, according to which social security funds are established based on the contributions owed by natural and legal persons participating in the public pension system, social security benefits inhering pursuant to the social security contributions paid;

d) equality principle, which ensures all participants in the public pension system, taxpayers and beneficiaries, a non-discriminatory treatment between persons in the same legal situation regarding the rights and obligations provided by law;

e) distribution principle, based on which the social security funds are redistributed to pay the obligations which are the duty of the public pension system, according to the law; 

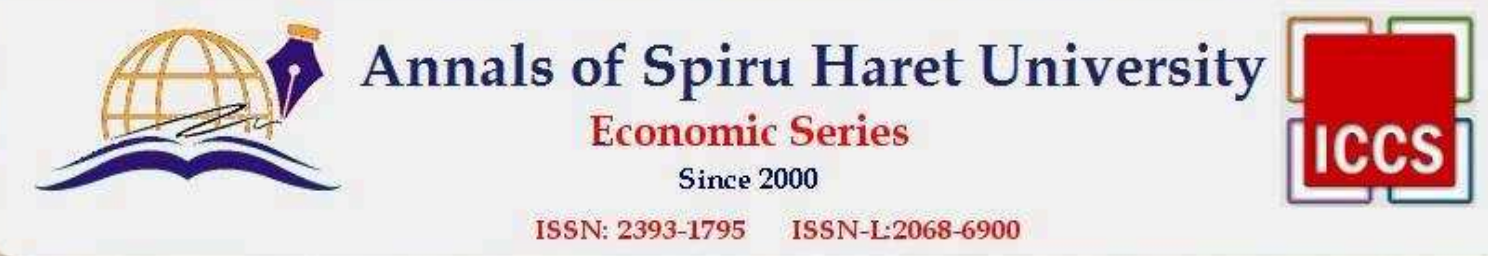

Issue 1/2016

f) social solidarity principle, whereby participants in the public pension system mutually assume obligations and enjoy rights to prevent, mitigate or eliminate the risks insured provided by law;

g) autonomy principle, based on the independent administration of the public pension system, according to law;

h) indefeasibility principle, according to which pension entitlement is not prescribed;

i) non-assignability principle, according to which the right to pension cannot be transferred, fully or partially.

\section{Conditions imposed by law for retirement pension}

Retirement pension is due to those insured who meet cumulatively, at the date of retirement, the conditions regarding the standard retirement age and the minimum contribution period realized in the public system.

Standard retirement age, minimum contribution period and complete contribution period are elements that underlie the opening of the pension rights.

Standard retirement age varies from one EU country to another, and is presented in Table no. 1. [Le Figaro, $15^{\text {th }}$ of February 2010]

According to Law no. 263/2010, in Romania, the standard retirement age is 65 for men and 63 for women.

For all categories of pensioners, standard retirement age may be reduced for:

- working in especial conditions;

- working in particular conditions;

- working in conditions of handicapped before becoming insured;

- politically persecuted, beneficiaries of Decree-Law no. 118/1990.

For men, reaching standard retirement age was achieved until December 2014 and for women, will be reached by January 2030 as set out in Appendix 5 of Law 263/2010. 


\section{Annals of Spiru Haret University \\ Economic Series \\ Since 2000 \\ ISSN: 2393-1795 ISSN-L:2068-6900}

Issue 1/2016

Table no. 1. The retirement age in $E U$ countries

\begin{tabular}{|l|l|l|l|l|}
\hline No. & \multicolumn{1}{|c|}{ Country } & \multicolumn{1}{|c|}{ Men (years) } & Women (years) & Average (years) \\
\hline 1 & Austria & 65 & 60 & 60,9 \\
\hline 2 & Belgium & 65 & 65 & 61,5 \\
\hline 3 & Bulgaria & 63 & 60 & 64,1 \\
\hline 4 & Czech Republic & 62 & 60 & 60,6 \\
\hline 5 & Cyprus & 65 & 65 & 63,5 \\
\hline 6 & Denmark & 65 & 65 & 61,3 \\
\hline 7 & Estonia & 63 & 61 & 62,1 \\
\hline 8 & Finland & 65 & 65 & 61,6 \\
\hline 9 & France & 60 & 60 & 59,3 \\
\hline 10 & Germany & 67 & 67 & 61,7 \\
\hline 11 & Greece & 65 & 60 & 61,4 \\
\hline 12 & Ireland & 65 & 65 & 64,1 \\
\hline 13 & Italy & 65 & 60 & 60,8 \\
\hline 14 & Latvia & 62 & 62 & 62,7 \\
\hline 15 & Lithuania & 62 & 60 & 59,9 \\
\hline 16 & United Kingdom & 65 & 60 & 63,1 \\
\hline 17 & Netherlands & 65 & 65 & 63,2 \\
\hline 18 & Poland & 65 & 65 & 59,3 \\
\hline 19 & Portugal & 65 & 65 & 62,6 \\
\hline 20 & Slovakia & 62 & 62 & 58,7 \\
\hline 21 & Slovenia & 63 & 61 & 59,8 \\
\hline 22 & Spain & 65 & 65 & 62,6 \\
\hline 23 & Sweden & 67 & 67 & 63,8 \\
\hline 24 & Hungary & 62 & 62 & 59,8 \\
\hline & & & & \\
\hline
\end{tabular}

Source: Le Figaro, $15^{\text {th }}$ of February 2010

For military personnel in activity, soldiers and volunteers, policemen and civil servants with special status from the penitentiary system, national defence system, public order and national security, both for women and men, there are some special regulation, such as: 


\section{Annals of Spiru Haret University \\ Economic Series \\ Since 2000 \\ ISSN: $2393-1795 \quad$ ISSN-L:2068-6900}

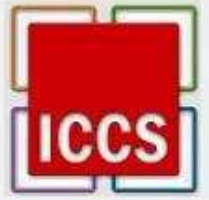

Issue $1 / 2016$

- the standard retirement age is 60 ;

- the minimum contribution period in specialty is 20 years;

- the complete contribution period is 30 years.

According to Law no. 263/2010, the contribution period is "the period of time for which were due social security contributions to the public pension system as well as that for which the insured parties with individual insurance statement or social insurance contract owed and paid social insurance contributions to the public pension system". Thus, the contribution period consists of summing the periods for which the contribution to the public social insurance budget was due by the employer and the insured.

In the public pension system, the periods without subscription, called assimilated periods, are as well assimilated to the contribution period, in which the insured:

a) has received a disability pension;

b) has attended the daily classes of university education, on condition of graduating with diploma;

c) has served the military service as conscript or draftee.

The minimum contribution period is 15 years for both women and men.

The complete contribution period is 35 years both for women and men.

The period during which a person works with individual labour contract represents seniority and, automatically, contribution period for retirement.

Pensioners with contribution periods in groups I and II of work, equated with especial conditions or particular conditions, receive additional scores.

The contribution periods realized in group I of work, especial conditions and/or other work conditions, lower than two years are capitalized in order to reduce the standard retirement age according to Table no. 2: 
Table no. 2. Contribution periods in group I of work

\begin{tabular}{|c|c|c|}
\hline \multirow{2}{*}{$\begin{array}{c}\text { Contribution periods in group I } \\
\text { of work, especial conditions } \\
\text { and other work conditions } \\
\text { (turned years) }\end{array}$} & \multicolumn{2}{|c|}{$\begin{array}{l}\text { Reducing the standard } \\
\text { retirement age with: }\end{array}$} \\
\hline & Years & Months \\
\hline 2 & 1 & - \\
\hline 3 & 1 & 6 \\
\hline 4 & 2 & - \\
\hline 5 & 2 & 6 \\
\hline 6 & 3 & - \\
\hline 7 & 3 & 6 \\
\hline 8 & 4 & - \\
\hline 9 & 4 & 6 \\
\hline 10 & 5 & - \\
\hline 11 & 5 & 6 \\
\hline 12 & 6 & - \\
\hline 13 & 6 & 6 \\
\hline 14 & 7 & - \\
\hline 15 & 7 & 6 \\
\hline 16 & 8 & - \\
\hline 17 & 8 & 6 \\
\hline 18 & 9 & - \\
\hline 19 & 9 & 6 \\
\hline 20 & 10 & - \\
\hline 21 & 10 & 6 \\
\hline 22 & 11 & - \\
\hline 23 & 11 & 6 \\
\hline 24 & 12 & - \\
\hline 25 & 12 & 6 \\
\hline 26 years and over & 13 & - \\
\hline
\end{tabular}

Source: Law no. 155 of 18 June 2015 amending Law no. 263/2010 on the unitary system of public pensions, art. 55 paragraph (1) a). 


\section{Annals of Spiru Haret University \\ Economic Series \\ Since 2000 \\ ISSN: 2393-1795 ISSN-L:2068-6900}

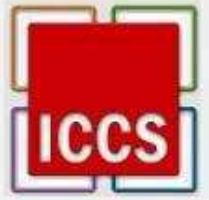

Issue $1 / 2016$

"Periods of seniority achieved in group II of work until $1^{\text {st }}$ of April 2001 represent contribution periods under especial conditions, in order to reduce the standard retirement age, except those realized under particular conditions.

Periods of seniority achieved in group I of work until $1^{\text {st }}$ of April 2001 in the activities that are assigned to particular conditions constitute contribution periods in particular conditions, in order to reduce the standard retirement age." [Law no. $155,18^{\text {th }}$ of June 2015]

The complete contribution period may be reduced as well in the following situations:

- completion of a period of 20 years in mining, in the underground;

- completion of a period of 20 years in artistic professions listed in Appendix 4 of Law 263/2010;

- completion of a period of 15 years in the radiation area I or 17 years in the radiation area II in research or exploitation of nuclear raw materials;

- completion of a particular contribution period under pre-existing severe disabilities or blindness.

\section{Basis for calculating the pension score}

The retirement pension amount depends on the number of years with paid contributions and the incomes obtained throughout the period of contribution.

The pension amount is determined by multiplying the annual average score of the insured with the value of a pension point (Vpp).

Annual average score represents the number of points realized by the insured, calculated by dividing the total score achieved throughout the period of activity to the number of years corresponding to the complete contribution period required by law at the time of retirement.

Annual average score (Pma) achieved by the insured is determined by dividing the number of points resulting from summing the annual scores to the number of years corresponding to the complete contribution period. 


\section{Annals of Spiru Haret University \\ Economic Series \\ Since 2000 \\ ISSN: 2393-1795 ISSN-L:2068-6900}

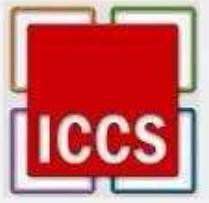

Issue $\mathbf{1 / 2 0 1 6}$

The annual score of the insured is determined by dividing to 12 the amount of the monthly scores obtained in that calendar year, regardless of the number of contribution months from that year.

The monthly score is the main factor used in determining the annual average score and is determined by dividing the wage rights a person has benefited of and to which was paid or were due social security contributions to the average earnings in that month, announced by the National Institute of Statistics.

The monthly score represents the number of points realized by the insured in a month, calculated by dividing the monthly gross earnings/ monthly gross balance or, if applicable, monthly insured income, which has represented the basis for calculating the social insurance contribution, to the average gross earnings in that month, announced by the National Institute of Statistics.

Basically, the monthly score is achieved by dividing the employee's salary to the gross earnings, which can be found on the official website of the National Institute of Statistics (www.insse.ro) from 1938 to the present day.

The value of the pension point should be increased each year by $100 \%$ of the average annual inflation rate, as determined by the Pension Law, plus $50 \%$ of the real growth of the realized average gross earnings. In this case, the indicators used to determine the value of the pension point for 2016 are the definitive ones, known in 2015 for 2016 (reported by the National Institute of Statistics).

For the months for which the National Institute of Statistics has not yet communicated the average gross earnings, it is used, for the whole month, the last average gross earnings communicated.

For those people that have realized contribution periods in more situations than one, for which the law provides different complete contribution period, the average annual score is determined by summing the annual average scores calculated according to the complete contribution periods provided by this law for each of those situations.

When calculating the annual average score, the yearly and monthly score, 5 decimals are used. 


\section{Annals of Spiru Haret University \\ Economic Series \\ Since 2000 \\ ISSN: 2393-1795 ISSN-L:2068-6900}

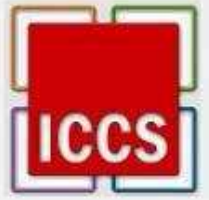

Issue $1 / 2016$

For example, an insured person has achieved in August 2014 a gross income of 2,120 lei. The gross average earning for August 2014 was 810.1024 lei. The monthly score is 2.61695 points $(21,200,000$ lei / $8,101,024$ lei). If it remains constant throughout the year, without intervening period in which that person had no job or wage increases or decreases occurred, then the employee would accumulate that year a yearly score of 2.61695 points.

According to the law, the pension is calculated by multiplying the pension point value, which is a standard one (is taken into account its value from the moment of submitting the file) and the annual average score.

\section{Pension $=$ pension point value $\times$ annual average score}

$$
P=V p p \times P m a
$$

In 2016, the pension point value is increased by five percentage points, according to Government Emergency Ordinance no. 57/2015. That is an increase from 830.2 lei, as was the point of retirement in 2015 , to 871.7 lei and translates into a slight increase in state pensions.

\section{Example:}

A man born in 1950 has realized a complete contribution period of 35 years, which according to Appendix no. 5 of the Law no. 263/2010 is considered as being the complete contribution period.

Suppose he gathered a total of 55.47287 points over those 35 years, then the annual average score is 1.58493 . This would be multiplied with the pension point value, which currently is 762.8 lei, and will result in a pension of 1,208 lei.

If until $1^{\text {st }}$ of April 2001 are used the data from the labour certificates and/or the certificates issued by former employers, subsequently in determining the monthly score is used the gross earning or, where appropriate, the monthly insured income which formed the basis for calculating the social insurance contribution.

The dynamics of the pension point value is presented in Table no. 3 . 
Issue 1/2016

Table no. 3. The dynamics of the pension point value

\begin{tabular}{|c|c|}
\hline Calendar date & Value (lei) \\
\hline April 2001 & 159232 \\
\hline June 2001 & 1693066 \\
\hline September 2001 & 1762482 \\
\hline December 2001 & 1885856 \\
\hline January 2002 & 1885856 \\
\hline March 2002 & 1999008 \\
\hline June 2002 & 2098959 \\
\hline September 2002 & 2161928 \\
\hline December 2002 & 2252729 \\
\hline January 2003 & 2265701 \\
\hline March 2003 & 2345001 \\
\hline June 2003 & 2408317 \\
\hline September 2003 & 2472138 \\
\hline December 2003 & 2548775 \\
\hline January 2004 & 2652000 \\
\hline March 2004 & 2705040 \\
\hline June 2004 & 2759141 \\
\hline September 2004 & 2869507 \\
\hline January 2005 & 2955592 \\
\hline July 2005 & 295,56 \\
\hline January 2006 & 323,05 \\
\hline September 2006 & 339,20 \\
\hline December 2006 & 396,20 \\
\hline September 2007 & 416 \\
\hline November 2007 & 541 \\
\hline January 2008 & 581,30 \\
\hline October 2008 & 697,50 \\
\hline April 2009 & 718,40 \\
\hline October 2009 & 732,80 \\
\hline January 2013 & 762,10 \\
\hline January 2014 & 790,70 \\
\hline January 2015 & 830.20 \\
\hline January 2016 & 871,70 \\
\hline
\end{tabular}

Source: My own example 


\section{Annals of Spiru Haret University \\ Economic Series \\ Since 2000 \\ ISSN: 2393-1795 ISSN-L:2068-6900}

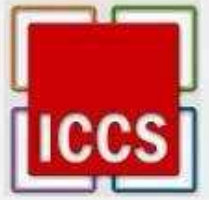

Issue $1 / 2016$

According to the Fiscal Code provisions by gross salary earning is understood "the incomes from salaries or assimilated to salaries which are subject to the income tax."

The following gains are not part of the basis for calculating the pension:

1. Gains in agreement or by piece.

2. Gains for occasional overtime payment.

3. Participation to benefits of the employees from the economic units.

4. The annual awards or during the year for outstanding achievements.

5. Occasional rewards received in some sectors.

6. Travel allowances.

7. Delegation, detachment and transfer allowances.

8. Copyrights.

9. Rights received on termination of employment.

10 . The $13^{\text {th }}$ salary.

11. Other bonuses which were not permanent.

\section{Early retirement}

To benefit from a pension before reaching the standard retirement age (early retirement or partial early retirement), each person must meet the complete contribution period required by law.

Early retirement can be approved, with up to 5 years before reaching the standard retirement age, for the persons who have made a contribution of at least 8 years bigger than the complete contribution period required by law.

Early pension amount is determined under the same conditions as for establishing the retirement pension.

On the conditions for granting the retirement pension, early retirement becomes retirement pension and is recalculated by adding the assimilated periods and any other contribution periods realized during the period of suspension of the anticipated pension.

Transforming anticipated pension in retirement pension takes place ex officio.

In case of partial (diminished) early retirement pensioners, the law provides that transition to retirement pension be done by request at the time these pensioners meet the age conditions for this transformation. 


\section{Annals of Spiru Haret University \\ Economic Series \\ Since 2000 \\ ISSN: $2393-1795 \quad$ ISSN-L:2068-6900}

Issue 1/2016

In some cases switching from the disability pension to retirement pension has as a result the reduction of the amount of the pension.

\section{Partial early retirement}

Partial early retirement pension can be approved with up to 5 years before reaching the standard retirement age, for the persons who have completed their contribution period, and those who have exceeded the complete contribution period with up to 8 years.

Law no. $263 / 2010$ on the unitary public pension system provides the tightening of the conditions for granting this category of pension, setting the penalty at $0.75 \%$ for each month of anticipation.

Anticipation cannot be bigger than 5 years ( 60 months) compared to standard retirement age prescribed by law, and the maximum penalty is $45 \%$ as compared to $30 \%$, as it was required by Law no. 19/2000.

The amount of the partial early retirement pension is determined from the retirement pension amount that would be due by reducing it to $0.75 \%$ for each month of anticipation, until meeting the conditions for obtaining the retirement pension.

By anticipation month we understand each month by which retirement is requested earlier than the normal retirement age stipulated by law.

\section{State pensions acquired by Romanian citizens abroad}

If a Romanian is working in countries within the European Union he can acquire the right to a pension in each of them.

Retirement houses from each EU country that person has worked will analyse the contributions paid to the pension fund from the respective country, but also the duration and amount of the contributions paid in other countries.

Each country calculates the pension the citizen should receive considering all the periods worked in any other country in the European Union.

For this, it sums all the periods worked in all the EU countries and sets up the theoretical pension, meaning the pension that state would have supposed to pay if all the contributions would have been paid in its pension fund, during the entire period. 


\section{Annals of Spiru Haret University \\ Economic Series \\ Since 2000 \\ ISSN: 2393-1795 ISSN-L:2068-6900}

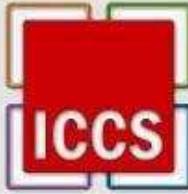

Issue 1/2016

The resulting value is then adjusted in order to reflect the actual duration of the contribution periods from that country ("pro rata provision").

If the person in question meets the eligibility criteria to receive a state pension in a particular country, regardless of the periods during which he contributed to the pension funds in other countries, the pension house calculates as well the national pension, known as "autonomous provision".

The national authority then compares the pro rata provision and the autonomous provision and takes into consideration the provision with the highest value in that country.

Finally, the person will receive a $\mathrm{P} 1$ form, which will explain the decision of each country regarding the pension request.

Example:

Margaret worked for 20 years in France and for 10 years in Spain. In both countries, a person becomes entitled to a pension if only has worked at least 15 years on its territory. Thus, each country will calculate Margaret's pension:

The house of pensions in France will make the following calculation:

- Will calculate the value of the national pension for her 20 years of working in France - let us say 800 Euros;

- Will calculate also the theoretical value of the pension Margaret would have received if she had worked in France the entire time (30 years) let us say 1,500 Euros. Then will establish the pro rata pension - that is the amount she should receive proportionally to the period worked in France: $€$ $1,500 \times 20$ years in France / 30 years in total $=€ 1,000$.

In conclusion, Margaret will have to receive from France the provision with the highest value: $€ 1,000$ per month.

The house of pensions in Spain will no longer calculate the national pension because Margaret has not worked there for at least 15 years. This will calculate only the amount at European level, based on the theoretical value of the pension Margarita would have received if she would had worked in Spain during this whole time (30 years) - say $€ 1,200$.

Then will establish the pro rata pension- that is the amount she deserves in proportion to the period she worked in Spain: $€ 1,200 \times 10$ years in Spain / 30 years in total $=€ 400$. 


\section{Annals of Spiru Haret University \\ Economic Series \\ Since 2000 \\ ISSN: $2393-1795 \quad$ ISSN-L:2068-6900}

Issue 1/2016

In total, Margaret will receive a pension of $€ 1,400$.

Regarding the pension payment, in general, the countries paying pensions transfer the due amounts in a bank account in the country of residence - if the person lives in one of the EU countries.

If the person in living outside the EU, one may need to open one bank account in each of the countries that pay the pensions.

The applicant cannot receive the state pension from the country he/she is living/the country he/she has last worked only when the legal retirement age in those countries has been reached.

However, if the applicant has acquired pension rights in other countries as well, he may receive the appropriate due parties only when the legal retirement age in those countries is reached.

\section{Example:}

Ingrid, from France, has worked in Denmark for 15 years. Towards the end of her career, she returned to France. At the age of 60 years (which is the legal retirement age in France) she requested her retirement.

At the age of 60 years, Ingrid has the right to a French part of the pension. But in case of the Danish pension, she will receive the appropriate amount only when she turns 67 , because that is the legal retirement age in Denmark (for the age group Ingrid falls into).

Eligibility periods:

In some EU countries, it is mandatory to have worked a certain period to gain the right to adequate pension.

In such cases, the pension house must apply the principle of cumulating the periods, meaning to take into account all periods that have been worked in other EU countries, as one would have been working in the concerned country.

\section{Example:}

Edward worked for 4 years in Germany, and 32 years in Portugal.

In Germany, a person cannot acquire pension rights because did not work at least 5 years. Normally, Edward would not benefit from the national pension system in Germany, since he worked there only for a period of 4 years. 


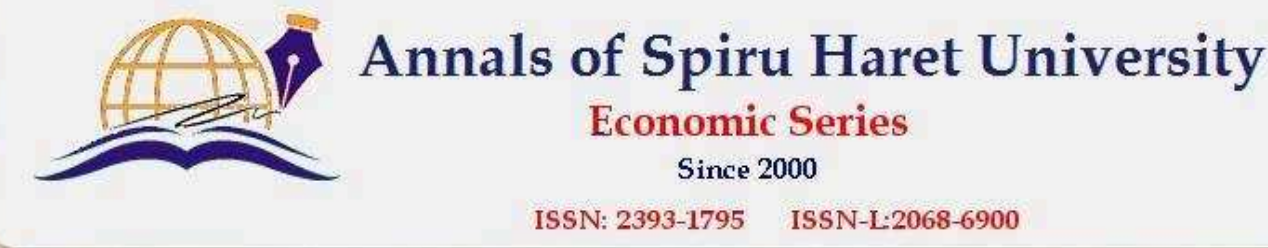

ISSN: 2393-1795 ISSN-L:2068-6900

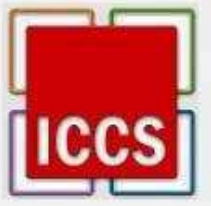

Issue $1 / 2016$

But the pension house in Germany had to take into account as well the years he has worked in Portugal. Therefore, the country has recognized his right to pension and pays the amount for the corresponding period of 4 years.

Since some EU countries do not provide pensions for short periods of work, a special rule may apply: the rights corresponding to the respective period are not lost, but are taken into account for establishing pensions in the countries where one has worked longer.

The retirement application must be submitted to the pension house in the country where one lives or the last country one has worked in. If one never worked in the country one lives, one shall submit the application for retirement to the country where one has last worked.

That country will be responsible for processing the request and will gather the evidence proving the contributions one paid in all countries in which one has worked.

\section{Conclusion}

Besides the negative political factors, we must take into account the unfavourable demographic trend of the pension system, the continuous decrease of the active population, as, on the one hand, Romania's population is aging, and on the other hand the birth rate is constantly decreasing.

Another factor that negatively affects the pension system is fiscal evasion, because if the salaries of the employees are not fully reported by the employers, the pension fund diminishes.

It is therefore important to adopt effective policies to increase collection and reduce evasion, which are simpler to adopt and implement.

It is also very important that after the significant reduction of CAS no other hasty measures for increasing pensions or for increasing the number of pensioners through early retirement mechanisms should be taken.

In the current conditions, without appropriate employment policies, we are dealing with a fragile equilibrium. The pensions' situation may become critical in the context of budget deficit targets more and more ambitious.

In the current European context regarding the modernization of the pension systems, Romania has adopted a system based on the diversification of the sources for obtaining the pensions, a system that would determine the financial security of the elders, through the implementation of private pensions. 


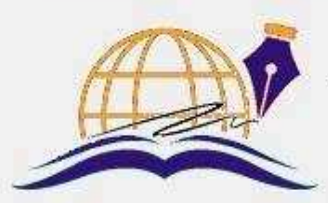

\section{Annals of Spiru Haret University}

Economic Series

Since 2000

ISSN: 2393-1795 ISSN-L:2068-6900

\section{Issue $1 / 2016$}

\section{References}

1. Law no. 263 (2010) on the unitary public pension system, published in the Official Gazette of Romania, Part I, no. 852 of 20 December 2010.

2. Law no. 155 (2015) amending Law no. 263/2010 on the unitary public pension.

3. Labour Code (2003), updated by Law 12/2015, published in the Official Gazette no. 52, 22 January 2015.

4. Law no. 97 (2015), published in the Official Gazette no. 316, 8 May 2015.

5. Dimensions of social inclusion in Romania (2008), National Institute of Statistics. 